white rump and back. I did not think the colour of the red or the upper parts was critical, nor pointed towards Hudsonian Godwit. Peterson's Field Guide to Western Birds depicts Bar-tailed Godwit as having an indistinct wing bar consistent with the bird seen at Porter Lake.
* EDITOR'S NOTE: The Bar-tailed Godwit that breeds in Alaska is reported to have a "poorly defined wing stripe" (R. H. Armstrong. 1980. A guide to the birds of Alaska. Alaska Northwest Publishing Co., Anchorage). In The birds of Canada, Godfrey mentions a single Canadian specimen from British Columbia.

\title{
EARLY FLEDGING RECORD OF WESTERN MEADOWLARK IN MANITOBA
}

MARTIN K. MCNICHOLL, 320 Markham Street, Toronto, Ontario. M6G 2K9

On 26 April 1969, while helping Robert J.Brown cannon-net SharptailedGrouse at Hodgson, Manitoba, we set a largemesh mist net at the edge of the grouse "dancing ground" to capture grouse that flushed before the cannon net landed. After one firing, we found a recently fledged Western Meadowlark in the net. The meadowlark had the general adult plumage markings, but these were not yet in full colour and the black $V$ was not yet well defined. The bird could fly only a few metres at a time. Since I did not have the correct band size for meadowlarks with me, I photographed the bird and released it.

Lanyon gave incubation periods for seven Western Meadowlark nests as 13 to 16 days, and Bent cited two earlier sources as stating 13 or 15 days. $^{3}{ }^{10}$ Bent quoted Dawson and Bowles as stating that Western Meadowlark young may leave the nest four or five days after hatching, but this is likely only in response to disturbance. ${ }^{3}$ Skaggs observed young from a nest of the Eastern Meadowlark to leave the nest 14 days after hatching, when they were "not able to fly 10 feet," a stage probably comparable to the Manitoba bird. ${ }^{25}$ Taking 14 days as a typical fledging period and adding a minimum incubation period of 13 days, the fledgling that we caught on 26 April must have been from a nest in which incubation started no later than 30 March, and probably a few days earlier.

Of 14 Manitoba records gleaned from the literature(Table 1), only one reports nesting in April. Similarly, nesting dates reported on 40 cards from Manitoba in the Prairie Nest Records Scheme ranged from 17 May to 22 July (Tab/e 2). Nesting dates for other provinces and states in the Northern Great Plains are comparable. For example, Bent listed egg 
Table 1. PUBLISHED NESTING DATES OF WESTERN MEADOWLARKS IN MANITOBA.

$\begin{array}{ll}\begin{array}{l}\text { Date } \\ \text { 4 June 1882 } \\ \text { 23 May 1926 } \\ \text { 30 May 1926 } \\ \text { 5 June 1926 }\end{array} & \begin{array}{l}\text { Location } \\ \text { Carberry } \\ \text { Portage la Prairie } \\ \text { Rosser } \\ \text { Headingly }\end{array} \\ \text { 22 May 1927 } & \begin{array}{l}\text { St. James } \\ \text { (Winnipeg) }\end{array} \\ \text { 30 May 1927 } & \begin{array}{l}\text { St. James } \\ \text { (Winnipeg) }\end{array} \\ \text { 27 May 1928 } & \begin{array}{l}\text { St. Vital } \\ \text { (Winnipeg) }\end{array} \\ \text { 13 April 1930 } & \begin{array}{l}\text { St. Vital } \\ \text { (Winnipeg) }\end{array} \\ \text { 10 May 1930 } & \text { Winnipeg } \\ \text { 15 July 1930 } & \begin{array}{l}\text { St. James } \\ \text { (Winnipeg) }\end{array} \\ \text { 27 May 1933 } & \begin{array}{l}\text { Norwood } \\ \text { (Winnipeg) }\end{array} \\ \text { 27 \& 30 May 1933 } & \begin{array}{l}\text { Winnipeg Beach } \\ \text { Whitemouth }\end{array} \\ \text { 23 July 1933 May 1961 } & \text { Benito }\end{array}$

\begin{tabular}{|c|c|}
\hline \multirow{6}{*}{$\begin{array}{l}\text { Details } \\
\text { young in nest; left by } 17 \text { June } \\
3 \text { eggs - C. L. Broley } \\
3 \text { young } 2 \text { days old - Broley } \\
2 \text { nests: } 5 \text { \& } 6 \text { eggs. - Nat. } \\
\text { Hist. Soc. Manitoba } \\
3 \text { eggs - M. Smith }\end{array}$} & Source \\
\hline & 27 \\
\hline & 11 \\
\hline & 11 \\
\hline & 11 \\
\hline & 12 \\
\hline $\begin{array}{l}3 \text { nests: } 5 \text { eggs, } 6 \text { eggs, } 5 \\
\text { young }-J . \text { Wardrope \& A. Geddes }\end{array}$ & 13 \\
\hline eggs - H. Mossop & 14 \\
\hline 4 eggs - J. V. Wilson & 15 \\
\hline eggs - G. Waight & 15 \\
\hline $\begin{array}{l}\text { eggs }+2 \text { cowbird eggs - } \\
\text { W. Cartwright }\end{array}$ & 15 \\
\hline young - Mrs. A. Haak & 16 \\
\hline gs - A. H. Skidmore & 16 \\
\hline ggs - V. Latta & 16 \\
\hline $\begin{array}{l}\text { ggs on } 23 \text { May, } 1 \text { hatched } \\
31 \text { May, } 4 \text { others on } 2 \text { June }\end{array}$ & 9 \\
\hline
\end{tabular}

dates from North Dakota for 20 nests

Western Meadowlarks do not normas from 2 May to 10 June, and 99 records in the Prairie Nest Records Scheme for Saskatchewan show earliest documented laying as 6 May (coincidently in 1969), with the earliest Alberta record on 16 cards being of a complete clutch on 17 May. $^{3}$ All these data confirm my impression that the Hodgson record was unusually early. ally overwinter in Manitoba (but see below). Criddle reported an average spring arrival date at one location (Aweme) for the years 1895-1920 as 1 April, with his earliest record as 21 March $1911 .{ }^{5}$ Oberholser listed Criddle's data and added two other Manitoba localities, where earliest reports were 20 and 26 March. ${ }^{22}$ Much later, Lawrence retained the end

\section{Table 2. DATA ON 40 NESTS OF WESTERN MEADOWLARK FROM MANITOBA IN PRAIRIE NEST RECORDS SCHEME.}

\section{Stage in Nesting}

Known construction dates

1 or 2 eggs in nest: known or probable laying records

Complete clutches of 3-7 eggs

Known hatching dates (first known hatch)

Nest found with young hatched
\#Records

1

10

21

6

2
Dates

26 May 1976

17 May - 20 June (date discovered)

18 May - 17 July

3 June - 1 July

25 June; 14 July 
of March to first week of April as the usual arrival date, but indicated that arrivals were known from the first few days of March. ${ }^{17}$ There are several other records of early arrivals in the prairie provinces, with records in Manitoba at least as early as 23 February. ${ }^{8} 24$ Moreover, in milder winters, large numbers may be present in the province by the beginning of the last week in Marcho Thus, the early nesting date reported here could involve a pair in which both adults arrived earlier than usual. However, 1969 was not a year in which large numbers appeared early; in fact, Mossop's earliest reported arrival that year was a rather late 8 April. ${ }^{21}$
Alternatively, one or both of the nesting adults may have over-wintered. Some of the "early migration" records reported above may actually represent previously undetected wintering birds. Although not usually a wintering species, there are several records of Western Meadowlarks in winter in Manitoba, Saskatchewan and Alberta. ${ }^{1} 24671819$ 23242829

\section{Acknowledgements}

The observation documented in this note took place incidental to studies of Robert J. Brown while both he and I were studying at the University of Manitoba. Cards of the Prairie Nest Records

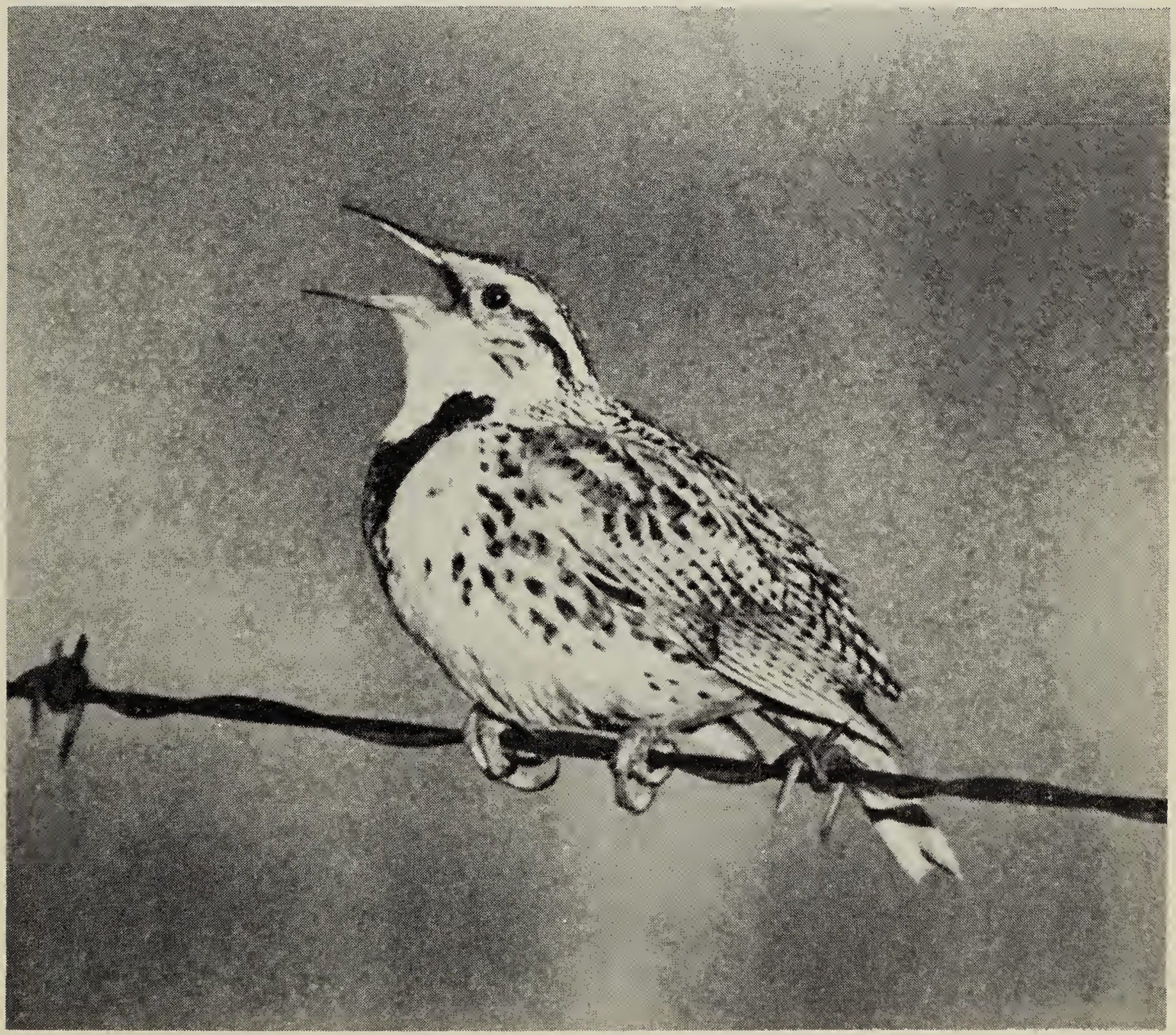


Scheme kindly loaned by Herbert W. R. Copland helped place the record in perspective. Comments on an earlier draft by Jerome $A$. Jackson and two anonymous reviewers were helpful in revising the manuscript.

${ }^{1}$ ANONYMOUS. 1945. Bird notes. Blue Jay $3(3) 24$.

${ }^{2}$ BELCHER, M. 1980. Birds of Regina. Revised ed. Sask. Nat. Hist. Soc. Spec. Publ. 12.

${ }^{3}$ BENT, A. C. 1958. Life histories of North American blackbirds, orioles, tanagers, and allies. U. S. Natl. Mus. Bull. 211.

${ }^{4}$ BRIMACOME, E. 1977. A winter meadowlark. Edmonton Nat. 5:58-59.

${ }^{5}$ CRIDDLE, N. 1922. A calendar of bird migration. Auk 39:41-49.

${ }^{6}$ HOOPER, D. F. 1970 . Meadowlark winters at Somme. Blue Jay 18:52.

7 HOOPER, D. 1981. Unusual winter bird records from Somme, Saskatchewan. Blue Jay 39:184.

$8 \mathrm{HORCH}$, P. 1981. Bird news. Man. Nat. Soc. Bull. 4(9):12-13

9 KOZIOI, M. 1961. Meadowlark's nest. Blue Jay 19:129.

10 LANYON, W. E. 1957. The comparative iology of the meadowlarks (Sturnella) in Wisconsin. Publ. Nuttall Ornithol. Club No. 1.

11 LAWRENCE, A. G. 1926. Breeding records. Chickadee Notes No. 272. Winnipeg Free Press 10 June 1926.

12 LAWRENCE, A.G. 1927. Breeding records. Chickadee Notes No. 323. Winnipeg Free Press 2 June 1927.

13 LAWRENCE, A.G. 1927. Breeding records. Chickadee Notes No. 328. Winnipeg Free Press 7 July 1927.

${ }^{14}$ LAWRENCE, A. G. 1928. Nesting reports. Chickadee Notes No. 376. Winnipeg Free Press 7 June 1928.
15 LAWRENCE, A. G. 1930. Breeding records for 1930. Part II. Chicadee Notes No. 488. Winnipeg Free Press 11 August 1930.

16 LAWRENCE, A. G. 1933. Breeding records for 1933. Part II. Chickadee Notes No. 646. Winnipeg Free Press 11 August 1933.

17 LAWRENCE, A. G. 1958. When the birds visit us. Winnipeg Free Press April 1958.

18 MOSSOP, H. 1960. Summer birds in winter. Chickadee Notes No. 270. Winnipeg Free Press 18 March 1960.

19 MOSSOP, H. 1960. Summer birds seen. Chickadee Notes No. 309. Winnipeg Free Press 21 December 1960.

20 MOSSOP, H. 1966. Migration reports. Chickadee Notes No. 585. Winnipeg Free Press 2 April 1966.

21 MOSSOP, H. 1969. (untitled). Chickadee Notes No. 742. Winnipeg Free Press 26 April 1969.

22 OBERHOLSER, H.C. 1921. The migration of North American birds. Second series. XV. Yellow-headed Blackbird and meadowlarks. Bird-Lore 23:78-82.

23 ROY, F. 1943. (Untitled). Blue Jay $1(3): 21$.

24 SADLER, T. S., and M. T. MYRES. 1976. Alberta birds 1961-1970. Prov. Mus. of Alberta Nat. Hist. Sect. Occas. Paper No. 1.

25 SKAGGS," M. B. 1976. Notes on a meadowlark nesting. Inland Bird Banding News 48:16-18.

26 STELFOX, J.G. 1958. Early meadowlark in Alberta. Can. Field-Nat. 72:171.

27 THOMPSON, E.E. 1891. The birds of Manitoba. Proc. U. S. Natl. Mus. 13:457-643.

28 WARD, A. 1955. The unwelcome albino. Blue Jay 13(2):15.

29 WHITE, E. J. 1960. Late records of summer birds. Blue Jay 18:52. 